\title{
Crystal Structure, Synthesis and Biological Activity of Ether and Ester Trans-Ferulic Acid Derivatives
}

\section{Marco A. Obregón-Mendoza1, M. Mirian Estévez-Carmona², Yair Alvarez-Ricardo1, William Meza-Morales ${ }^{1}$, Carolina Escobedo-Martínez ${ }^{3}$, Manuel Soriano-García ${ }^{1}$, Raúl G. Enríquez ${ }^{1^{*}}$}

${ }^{1}$ Instituto de Química, Universidad Nacional Autónoma de México, Ciudad de México, México

${ }^{2}$ Escuela Nacional de Ciencias Biológicas, Instituto Politécnico Nacional, México City, México

${ }^{3}$ Departamento de Farmacia, División de Ciencias Naturales y Exactas, Universidad de Guanajuato, Guanajuato, México

Email: *enriquezhabib@gmail.com

How to cite this paper: Obregón-Mendoza, M.A., Estévez-Carmona, M.M., Alvarez-Ricardo, Y., Meza-Morales, W., Escobedo-Martínez, C., Soriano-García, M. and Enríquez, R.G. (2018) Crystal Structure, Synthesis and Biological Activity of Ether and Ester Trans-Ferulic Acid Derivatives. International Journal of Organic Chemistry, 8, 359-377.

https://doi.org/10.4236/ijoc.2018.84028

Received: October 26, 2018

Accepted: December 11, 2018

Published: December 14, 2018

Copyright (c) 2018 by authors and Scientific Research Publishing Inc. This work is licensed under the Creative Commons Attribution International License (CC BY 4.0).

http://creativecommons.org/licenses/by/4.0/ (c) (i) Open Access

\begin{abstract}
The structures of methoxymethyl (E)-3-(4-hydroxy-3-methoxyphenyl)acrylate, 2; (E)-3-(3-methoxy-4-(methoxymethoxy)phenyl)acrylic acid, 3; methyl (E)3-(4-(benzyloxy)-3-methoxyphenyl)acrylate, 4; benzyl (E)-3-(4-(benzyloxy)3-methoxyphenyl)acrylate, 6; and (E)-3-(4-(benzyloxy)-3-methoxyphenyl)acrylic acid, 7; were established by spectroscopic and X-ray diffraction studies. Structure 2 is a new compound. Compounds with free phenolic hydroxyls v.gr. methyl (E)-3-(4-hydroxy-3-methoxyphenyl)acrylate 1, 2 and benzyl(E)-3-(4-hydroxy-3-methoxyphenyl)acrylate 5, showed scavenging freeradical and antioxidant activity while moderate scavenging free-radical was observed in compound 3. Moderate inhibition of lipid peroxidation was observed for 7. Compound 5 exerted significant inhibition of cell growth in PC-3, K562 tumor cell lines and 4 exhibited the largest cytotoxic effect upon the K562 cell line.
\end{abstract}

\section{Keywords}

Trans-Ferulic Acid, Crystal Structures, Antioxidant Activity, Antitumor, Scavenging Free-Radicals

\section{Introduction}

Ferulic acid (FA) is a phenolic derivative of cinnamic acid, which exhibits a wide spectrum of biomedical activities [1]. Many staple foods such as grain bran, 
whole-grain foods, citrus fruits, banana, coffee, orange juice, eggplant, bamboo shoots, beetroot, cabbage, spinach and broccoli are among the richest sources of FA [2]. This compound is present in seeds and leaves, both in its free form and in its covalent-conjugated form, in plant cell-wall polysaccharides, glycoproteins, polyamides, lignin and hydroxy fatty acids. FA confers rigidity to the cell-wall and it is a precursor to other important organic compounds such as diferulic acid and curcumin [3]. Several reports have described the biological effects of FA, for example, as an antioxidant [4], anti-inflammatory and anticarcinogenic [5].

The well-known antioxidant activity of FA has been related to its phenolic nucleus and extensive chain conjugation that forms a resonance-stabilized phenoxy radical ion [4]. Since the hydroxyl and phenoxy groups of FA donate electrons to quench free radicals [6], FA can be used as a renewable, aromatic scaffold for conversion into novel, and useful products in the food, pharmaceutical and cosmetic industries. The ability of FA to inhibit peroxidation of fatty acids finds uses such as preservative for oranges or to inhibit the autoxidation of linseed oil. It is also employed in the industry of cosmetic skin lotions [4]. FA is used during oxidative-reductive depolymerization (ORD) of polysaccharides to protect both guar gum and cassava starch from thermal degradation [7].

The synthesis of new derivatives of FA in general has been aimed to improve its chemical, physicochemical and biological properties, in particular in its esterified form at the acidic moiety, which increases both radical scavenging activity and partition coefficient [8]. However, it is known that the blockade of the phenolic groups of FA can limit its antioxidant potential.

In the present report, the synthesis, spectroscopic characterization, X-ray analysis and biological activity of ether and ester derivatives of FA is described and it is depicted in Scheme 1. We also highlight the importance of the free hydroxyl and phenolic group in relation to the antioxidant and cytotoxic activity of FA and how the protection of these functional groups reduces their biological activity.

Compounds 1, 3, 4, 5, 6 and 7 have been previously reported while 2 is a new compound [9] [10] [11] [12] [13].

\section{Experimental}

\subsection{Physical Measurements}

All chemicals were reagent grade and were used as purchased. Solvents were purified by standard methods [14].

Melting points were determined on an Electrothermal IA9100 digital melting point apparatus and are uncorrected. IR absorption spectra were recorded in the $4000-400 \mathrm{~cm}^{-1}$ range as $\mathrm{KBr}$ pellets on a Perkin Elmer 283-B spectrophotometer. ${ }^{1} \mathrm{H}$ and ${ }^{13} \mathrm{C}$ NMR spectra were recorded in $\mathrm{CDCl}_{3}$ on a Bruker $500 \mathrm{MHz}$ spectrometer using TMS as an internal reference. NMR spectra were processed with MestReNOVA 12.0.0 software. 


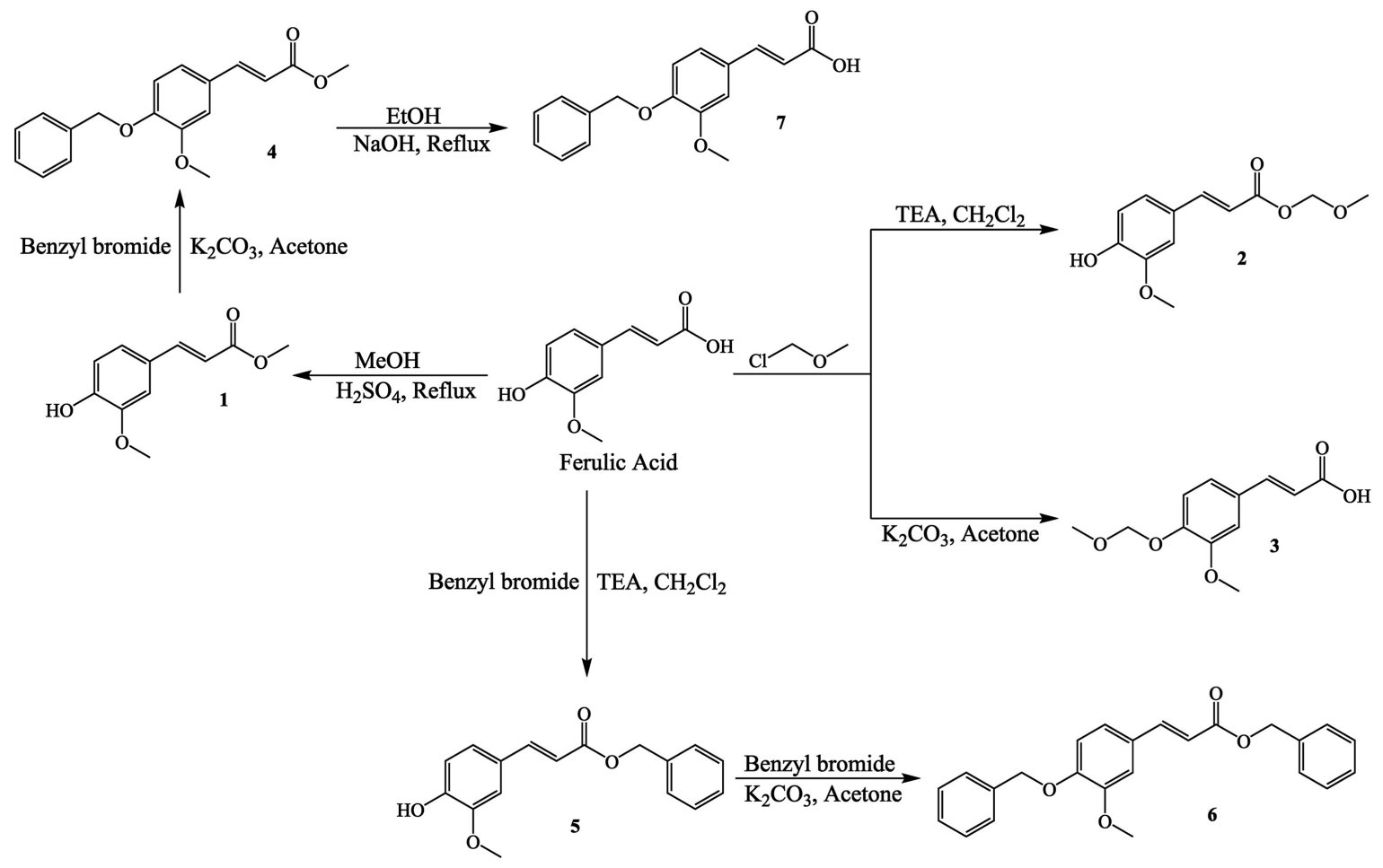

Scheme 1. Synthetic pathway for FA derivatives.

The mass spectrometry spectra were recorded in equipment MStation JMS-700 or Jeol, SX 102A using electron ionization impact or fast atom bombardment (FAB) mode.

X-ray data were collected on a Bruker APEX2 CCD area detector with a graphite monochromator and Mo $K \alpha$ radiation $(\lambda=0.71073 \AA)$ at room temperature with $\omega$ scan mode. All collected data were reduced using SAINTV8.27B [15]. These data are shown in Table 1.

\subsection{Synthesis of Compounds}

Methyl (E)-3-(4-hydroxy-3-methoxyphenyl)acrylate (1). 5 meq of FA were dissolved in $20 \mathrm{~mL}$ of anhydrous methanol and $0.2 \mathrm{ml}$ of $\mathrm{H}_{2} \mathrm{SO}_{4}$ were added and the mixture was refluxed for 6 hours. The reaction was quenched by the addition of $\mathrm{NaHCO}_{3}$ until it reached $\mathrm{pH} 6$ and the mixture was extracted with ethyl acetate $(3 \times 20 \mathrm{~mL})$. The combined extracts were dried over anhydrous $\mathrm{Na}_{2} \mathrm{SO}_{4}$, then filtered and the solvent removed in vacuo, $82 \%$ yield, yellowish liquid. ${ }^{1} \mathrm{H}$ NMR (500 MHz, chloroform-d); $\delta 7.62(\mathrm{~d}, J=15.9 \mathrm{~Hz}, 1 \mathrm{H}$ ), 7.07 (ddd, $J=8.2,2.0,0.5$ $\mathrm{Hz}, 1 \mathrm{H}), 7.02(\mathrm{~d}, J=2.0 \mathrm{~Hz}, 1 \mathrm{H}), 6.92(\mathrm{~d}, J=8.2 \mathrm{~Hz}, 1 \mathrm{H}), 6.29(\mathrm{~d}, J=15.9 \mathrm{~Hz}$, $1 \mathrm{H}), 5.96(\mathrm{~s}, 1 \mathrm{H}), 3.92(\mathrm{~s}, 3 \mathrm{H}), 3.80(\mathrm{~s}, 3 \mathrm{H})$ spectrum is shown in Figure $1 .{ }^{13} \mathrm{C}$ NMR (125 MHz, chloroform-d) $\delta 167.70,147.98,146.76,144.93,126.92,122.99$, $115.12,114.72,109.38,55.90,51.56$, IR; 3379.82, 2942.22, 1705.06, 1510.97, $1429.46,1236.41 \mathrm{~cm}^{-1}$, MS [208 $\left.{ }^{+}\right]$.

Methoxymethyl (E)-3-(4-hydroxy-3-methoxyphenyl)acrylate (2). To a solution of 1.0 meq of $\mathrm{FA}(0.1940 \mathrm{~g})$ in $30 \mathrm{ml}$ of $\mathrm{CH}_{2} \mathrm{Cl}_{2}, 1.1 \mathrm{meq}$ of triethylamine 
and 1.1 meq of chloromethyl methyl ether (Cl-MOM) were added. The reaction mixture was stirred at room temperature until the disappearance of the starting material was observed by TLC (Hexane:EtOAc: 70:30). The reaction was quenched by evaporation of the solvents of reaction and the mixture was extracted with EtOAc $(3 \times 20 \mathrm{~mL})$, yield $68 \%$, mp $80^{\circ} \mathrm{C} .{ }^{1} \mathrm{H}$ NMR $(500 \mathrm{MHz}$, chloroform-d); $\delta 7.68(\mathrm{~d}, J=15.9 \mathrm{~Hz}, 1 \mathrm{H}), 7.08(\mathrm{~m}, 1 \mathrm{H}), 7.04(\mathrm{~d}, J=2.0 \mathrm{~Hz}, 1 \mathrm{H})$, $6.92(\mathrm{~d}, J=8.2 \mathrm{~Hz}, 1 \mathrm{H}), 6.31(\mathrm{~d}, J=15.9 \mathrm{~Hz}, 1 \mathrm{H}), 6.00(\mathrm{~s}, 1 \mathrm{H}), 5.37(\mathrm{~s}, 2 \mathrm{H}), 3.93$

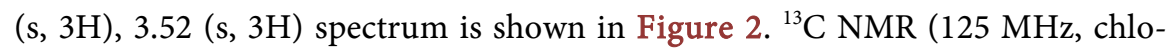
roform-d) $\delta 166.59,148.18,146.80,145.78,126.76,123.19,114.86,114.76$, $109.44,90.35,57.55,55.90$. IR; 3266.48, 2944.22, 1716.75, $1627.83,1508.79 \mathrm{~cm}^{-1}$. MS $\left[238^{+}\right]$.

(E)-3-(3-methoxy-4-(methoxymethoxy)phenyl)acrylic acid (3). To a solution of the $1.0 \mathrm{meq}$ of $\mathrm{FA}(0.1940 \mathrm{~g})$ in $10 \mathrm{ml}$ of acetone 1.0 meq of $\mathrm{K}_{2} \mathrm{CO}_{3}$ anhydrous and 1.1 meq of chloromethyl methyl ether (Cl-MOM) were added. The reaction mixture was stirred at room temperature until the disappearance of the starting material was observed by TLC (Hexane:EtOAc: 70:30). The reaction was quenched by filtration of the potassium salts and the solvent was removed in vacuum, yield $92 \%, \mathrm{mp} 134.8^{\circ} \mathrm{C}$. ${ }^{1} \mathrm{H}$ NMR (500 MHz, chloroform-d); $\delta 7.74$ (d, $J$ $=15.99 \mathrm{~Hz}, 1 \mathrm{H}), 7.17(\mathrm{~d}, J=8.28 \mathrm{~Hz}, 1 \mathrm{H}), 7.10(\mathrm{~m}, 2 \mathrm{H}), 6.34(\mathrm{~d}, J=15.99 \mathrm{~Hz}, 1 \mathrm{H})$, $5.28(\mathrm{~s}, 2 \mathrm{H}), 3.93(\mathrm{~s}, 3 \mathrm{H}), 3.52(\mathrm{~s}, 3 \mathrm{H})$ spectrum is shown in Figure $3 .{ }^{13} \mathrm{C} \mathrm{NMR}$ (125 MHz, chloroform-d) $\delta 172.56,149.89,148.97,146.86,128.43,122.74,115.82$, 115.54, 110.57, 95.19, 56.37, 55.97, IR; 3438.01, 1688.78, 1622.87, $1506.04 \mathrm{~cm}^{-1}$, MS $\left[239^{+}\right]$.

Table 1. Data collection and handling for compounds 2, 3, 4, 6, and 7.

\begin{tabular}{|c|c|c|c|c|c|}
\hline Compound & 2 & 3 & 4 & 6 & 7 \\
\hline Empirical formula & $\mathrm{C}_{12} \mathrm{H}_{14} \mathrm{O}_{5}$ & $\mathrm{C}_{12} \mathrm{H}_{14} \mathrm{O}_{5}$ & $\mathrm{C}_{18} \mathrm{H}_{18} \mathrm{O}_{4}$ & $\mathrm{C}_{24} \mathrm{H}_{22} \mathrm{O}_{4}$ & $\mathrm{C}_{17} \mathrm{H}_{16} \mathrm{O}_{4}$ \\
\hline Formula weight & 238.23 & 238.23 & 298.32 & 374.41 & 284.30 \\
\hline Crystal external appearance & Colorless prism & Colorless prism & Colorless prism & Colorless prism & Colorless prism \\
\hline Diffractometer & Bruker APEX2 CCD & Bruker APEX2 CCD & Bruker APEX2 CCD & Bruker APEX2 CCD & Bruker APEX2 CCD \\
\hline Scanmode & Omega scans & Omega scans & Omega scans & Omega scans & Omega scans \\
\hline $\begin{array}{l}\text { Theta range } \\
\text { for data collection }\end{array}$ & 2.89 to $25.40 \mathrm{deg}$ & 2.73 to $25.37 \mathrm{deg}$ & 2.37 to $25.29 \mathrm{deg}$ & 2.30 to $25.41 \mathrm{deg}$ & 2.48 to $25.32 \mathrm{deg}$ \\
\hline Wavelength & Mo Ka $(0.71073 \AA ̊)$ & Mo Ka $(0.71073 \AA)$ & Mo Ka (0.71073 ̊̊) & Mo K $\alpha(0.71073 \AA)$ & Mo K $\alpha(0.71073 \AA)$ \\
\hline Program system & SHELXTL & SHELXTL & SHELXTL & SHELXTL & SHELXTL \\
\hline Structure determination & $\begin{array}{c}\text { Direct methods } \\
\text { (SHELXS-2014/7) }\end{array}$ & $\begin{array}{c}\text { Direct methods } \\
\text { (SHELXS-2014/7) }\end{array}$ & $\begin{array}{l}\text { Direct methods } \\
\text { (SHELXS-2014/7) }\end{array}$ & $\begin{array}{c}\text { Direct methods } \\
\text { (SHELXS-2014/7) }\end{array}$ & $\begin{array}{l}\text { Direct methods } \\
\text { (SHELXS-2014/7) }\end{array}$ \\
\hline Refinement method & $\begin{array}{c}\text { Full-matrix } \\
\text { least-squares on } \mathrm{F}^{2} \\
(\mathrm{SHELXL-2014/7)}\end{array}$ & $\begin{array}{c}\text { Full-matrix } \\
\text { least-squares on } \mathrm{F}^{2} \\
(\mathrm{SHELXL-2014/7)}\end{array}$ & $\begin{array}{c}\text { Full-matrix } \\
\text { least-squares on } \mathrm{F}^{2} \\
(\mathrm{SHELXL-2014/7)}\end{array}$ & $\begin{array}{c}\text { Full-matrix } \\
\text { least-squares on } F^{2} \\
(\text { SHELXL-2014/7) }\end{array}$ & $\begin{array}{c}\text { Full-matrix } \\
\text { least-squares on } \mathrm{F}^{2} \\
(\text { SHELXL-2014/7) }\end{array}$ \\
\hline
\end{tabular}



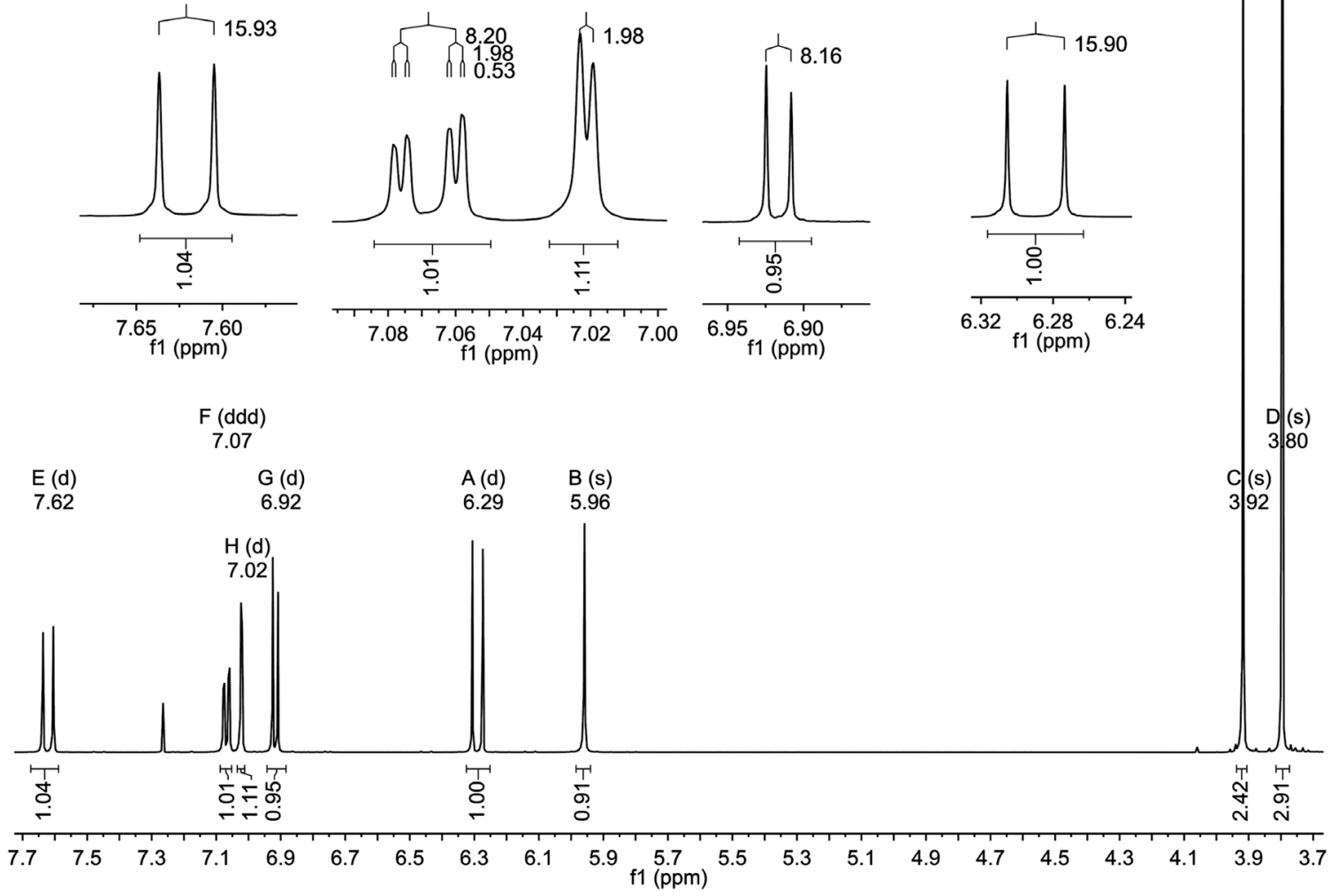

Figure $1 .{ }^{1} \mathrm{H}$ NMR spectrum of compound 1 .

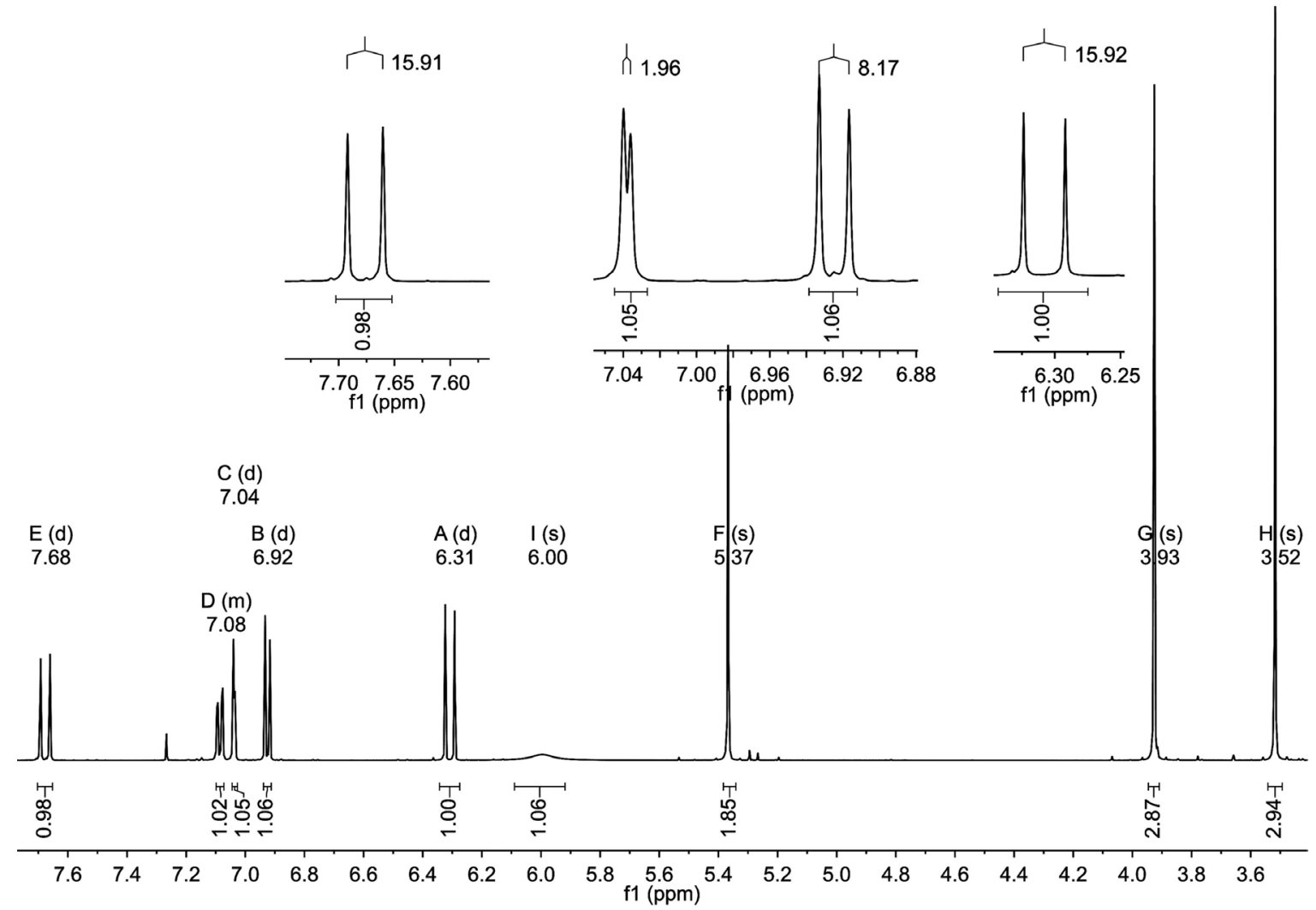

Figure 2. ${ }^{1} \mathrm{H}$ NMR spectrum of compound 2. 


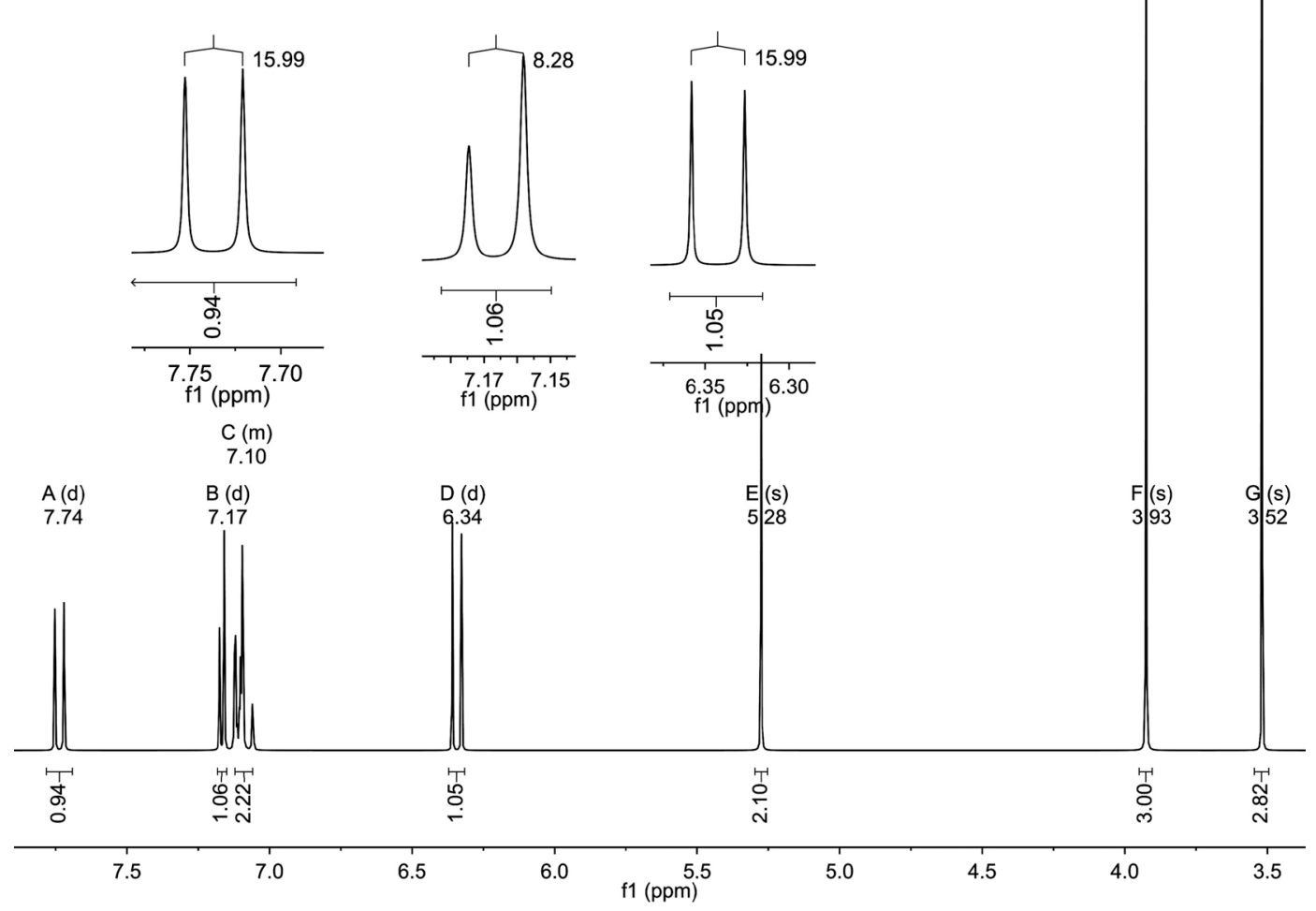

Figure $3 .{ }^{1} \mathrm{H}$ NMR spectrum of compound 3.

Methyl (E)-3-(4-(benzyloxy)-3-methoxyphenyl)acrylate (4). 1 meq of compound 1 was dissolved in $30 \mathrm{~mL}$ of anhydrous acetone and 1 meq of $\mathrm{K}_{2} \mathrm{CO}_{3}$ and 1.1 meq of benzyl bromide were stirred at room temperature. The reaction was followed by TLC (Hexane:EtOAc: 70:30). The solvent was removed in vacuo, yield 78\%, mp 97.1 ${ }^{\circ} \mathrm{C} .{ }^{1} \mathrm{H}$ NMR (500 MHz, chloroform-d); $\delta 7.61(\mathrm{~d}, J=15.9 \mathrm{~Hz}$, $1 \mathrm{H}), 7.42(\mathrm{ddt}, J=7.6,1.4,0.7 \mathrm{~Hz}, 2 \mathrm{H}), 7.36(\mathrm{tt}, J=6.6,0.8 \mathrm{~Hz}, 2 \mathrm{H}), 7.30(\mathrm{~m}$, $1 \mathrm{H}), 7.06(\mathrm{~d}, J=2.0 \mathrm{~Hz}, 1 \mathrm{H}), 7.02(\mathrm{ddd}, J=8.2,2.1,0.5 \mathrm{~Hz}, 1 \mathrm{H}), 6.86(\mathrm{~d}, J=8.3$ $\mathrm{Hz}, 1 \mathrm{H}), 6.30$ (d, $J=15.9 \mathrm{~Hz}, 1 \mathrm{H}), 5.18(\mathrm{~s}, 2 \mathrm{H}), 3.91$ (s, 3H), 3.79 (s, 3H) spectrum is shown in Figure $4 .{ }^{13} \mathrm{C}$ NMR $(125 \mathrm{MHz}$, chloroform-d) $\delta 167.58,150.24$, $149.74,145.12,144.69,143.62,136.55,128.58,127.96,127.71,127.16,122.30$, $115.59,113.44,110.27,70.82,55.95,51.54$, IR; 2942.82, 1700.03, 1627.76, $1592.64,1508.58,1255.42 \mathrm{~cm}^{-1}$, MS $\left[300^{+}\right]$.

Benzyl (E)-3-(4-hydroxy-3-methoxyphenyl)acrylate (5). To a solution of 1.0 meq of FA $(0.1940 \mathrm{~g})$ in $30 \mathrm{ml}$ of $\mathrm{CH}_{2} \mathrm{Cl}_{2} 1.1 \mathrm{meq}$ of triethylamine $1.1 \mathrm{meq}$ of benzyl bromide were added. The reaction mixture was stirred at room temperature and followed by TLC (Hexane:EtOAc: 70:30). After removal of solvent reaction was partitioned with EtOAc $(3 \times 20 \mathrm{~mL})$ and $\mathrm{H}_{2} \mathrm{O}$, the combined extracts were dried over anhydrous $\mathrm{Na}_{2} \mathrm{SO}_{4}$, filtered, and the solvent was removed in vacuum, yield $73 \%$, mp $57.3^{\circ} \mathrm{C} .{ }^{1} \mathrm{H}$ NMR $(500 \mathrm{MHz}$, chloroform-d) $\delta 7.65(\mathrm{~d}, J=$ $15.9 \mathrm{~Hz}, 1 \mathrm{H}), 7.38(\mathrm{~m}, 5 \mathrm{H}), 7.06(\mathrm{ddd}, J=8.1,2.0,0.5 \mathrm{~Hz}, 1 \mathrm{H}), 7.02(\mathrm{~d}, J=2 \mathrm{~Hz}$, $1 \mathrm{H}) 6.91(\mathrm{~d}, J=8.2 \mathrm{~Hz}, 1 \mathrm{H}), 6.34(\mathrm{~d}, J=15.9 \mathrm{~Hz}, 1 \mathrm{H}), 5.90(\mathrm{~s}, 1 \mathrm{H}), 5.24(\mathrm{~s}, 2 \mathrm{H})$, $3.90(\mathrm{~s}, 3 \mathrm{H})$ spectrum is shown in Figure $5 .{ }^{13} \mathrm{C}$ NMR (125 MHz, chloroform-d) $\delta 167.05,148.03,146.75,145.23,136.17,128.56,128.24,128.19,126.93,123.13$, 
115.22, 114.71, 109.33, 66.22, 55.91, IR; 3404.3, 2941.23, 1703.49, 1632.44, $1593.13,1514.53 \mathrm{~cm}^{-1}$, MS $\left[286^{+}\right]$.
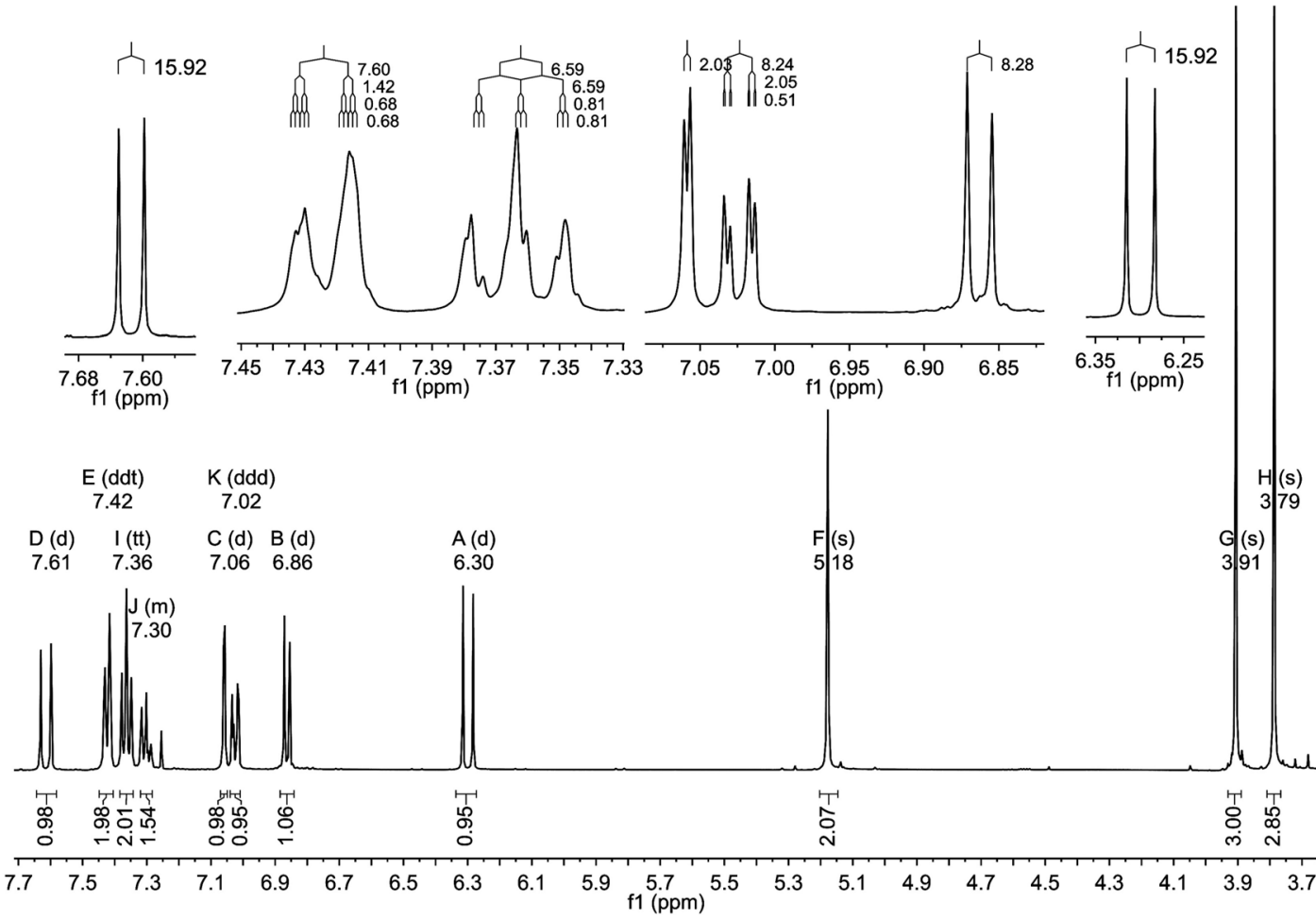

Figure 4. ${ }^{1} \mathrm{H}$ NMR spectrum of compound 4.

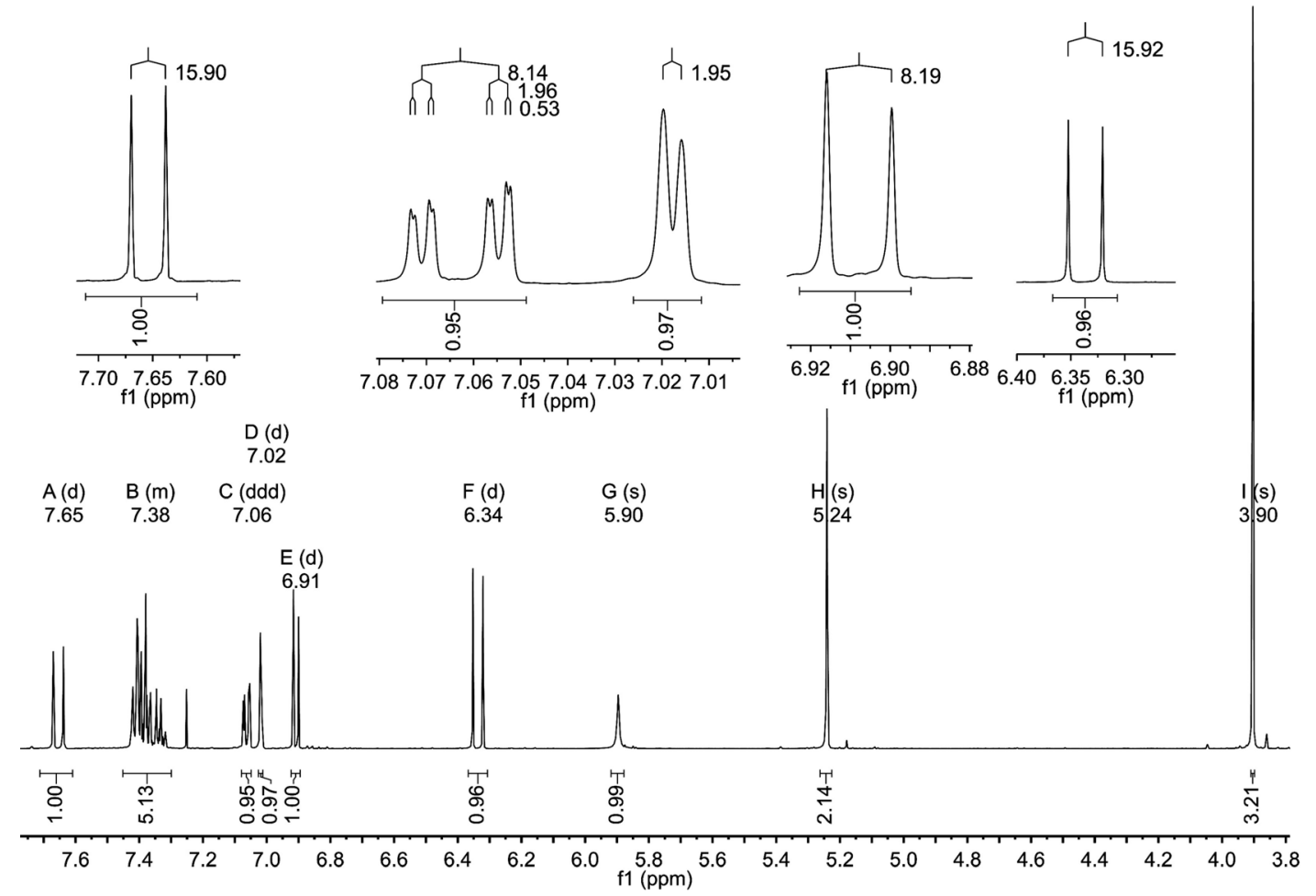

Figure 5. ${ }^{1} \mathrm{H}$ NMR spectrum of compound 5. 
Benzyl (E)-3-(4-(benzyloxy)-3-methoxyphenyl)acrylate (6). 1 meq of compound 5 was solved in $30 \mathrm{~mL}$ of acetone anhydrous and was added 1 meq of $\mathrm{K}_{2} \mathrm{CO}_{3}$ and finally was added $1.1 \mathrm{meq}$ of benzyl bromide. The reaction mixture was stirred at room temperature until the disappearance of the starting material was observed by TLC (Hexane:EtOAc: 70:30). The reaction was quenched by filtration of potassium salts and the solvent was removed in vacuum, yield $84 \%$, mp 86. $3^{\circ} \mathrm{C} .{ }^{1} \mathrm{H}$ NMR (500 MHz, chloroform-d); $\delta 7.65$ (d, $\left.J=15.9 \mathrm{~Hz}, 1 \mathrm{H}\right), 7.45$ - $7.27(\mathrm{~m}, 10 \mathrm{H}), 7.06$ (d, $J=2.0 \mathrm{~Hz}, 1 \mathrm{H}), 7.02$ (ddd, $J=8.3,2.1,0.5 \mathrm{~Hz}, 1 \mathrm{H}), 6.86$ $(\mathrm{d}, J=8.3 \mathrm{~Hz}, 1 \mathrm{H}), 6.35$ (d, $J=15.9 \mathrm{~Hz}, 1 \mathrm{H}), 5.24(\mathrm{~s}, 2 \mathrm{H}), 5.18(\mathrm{~s}, 2 \mathrm{H}), 3.90(\mathrm{~s}$, $3 \mathrm{H})$ spectrum is shown in Figure $6 .{ }^{13} \mathrm{C}$ NMR $(125 \mathrm{MHz}$, chloroform-d) $\delta$ $166.97,150.32$, 149.76, 145.62, 145.03, 136.56, 136.16, 128.61, 128.57, 128.24, $128.19,128.00,127.70,127.18,122.44,115.67,113.43,110.22,70.85,66.23,55.96$, IR; $2937.39,1697.95,1628.78,1505.19,1255.53,1157.91,1135.79 \mathrm{~cm}^{-1}$, MS [molecular ion not observed].

(E)-3-(4-(benzyloxy)-3-methoxyphenyl)acrylic acid (7). To 1 meq of compound 4 was solved in $20 \mathrm{~mL}$ of ethanol and $10 \mathrm{~mL}$ of one solution $1 \mathrm{M}$ of $\mathrm{NaOH}$ were added the mixture refluxed for 40 minutes. The reaction was terminated by addition of $\mathrm{HCl} 1 \mathrm{~N}$ until $\mathrm{pH} 6$ and the mixture partitioned with ethyl acetate $(3 \times 20 \mathrm{~mL})$ and $\mathrm{H}_{2} \mathrm{O}$. The combined extracts were dried over anhydrous $\mathrm{Na}_{2} \mathrm{SO}_{4}$, filtered, and the solvent was removed in vacuum; yield 74\%. mp 192.9 ${ }^{\circ} \mathrm{C} .{ }^{1} \mathrm{H}$ NMR (500 MHz, chloroform-d); $\delta 7.58(\mathrm{~d}, J=15.9 \mathrm{~Hz}$, $1 \mathrm{H}), 7.43(\mathrm{~m}, 2 \mathrm{H}), 7.37(\mathrm{~m}, 2 \mathrm{H}), 7.31(\mathrm{~m}, 1 \mathrm{H}), 7.08(\mathrm{~d}, J=2.0 \mathrm{~Hz}, 1 \mathrm{H}), 7.03(\mathrm{~m}$, $1 \mathrm{H}), 6.89(\mathrm{~d}, J=8.3 \mathrm{~Hz}, 1 \mathrm{H}), 6.29(\mathrm{~d}, J=15.9 \mathrm{~Hz}, 1 \mathrm{H}), 5.17(\mathrm{~s}, 2 \mathrm{H}), 3.91(\mathrm{~s}, 3 \mathrm{H})$ spectrum is shown in Figure 7. ${ }^{13} \mathrm{C}$ NMR (125 MHz, chloroform-d) $\delta 168.86$, $150.03,149.70,144.38,136.58,128.56,127.96,127.92,127.24,122.23,116.74$, 113.50, 110.30, 70.78, 55.95, IR; 2968.68, 1669.68, 1592.66, 1423.76, $1265.73 \mathrm{~cm}^{-1}$, MS $\left[285^{+}\right]$.

\subsection{Scavenging Activity of DPPH Free Radicals}

The free radical scavenging activity was measured using a modified method from Mellors and Tappel [16]. The test was carried out on 96-well microplates. A $50 \mu \mathrm{L}$ aliquot of the solution of the test compound was mixed with $150 \mu \mathrm{L}$ of an ethanol solution of DPPH (final concentration $100 \mu \mathrm{M}$ ). This mixture was incubated at $37^{\circ} \mathrm{C}$ for $30 \mathrm{~min}$, and the absorbance was then measured at $515 \mathrm{~nm}$ using a BioTek microplate reader SYNERGY HT. The inhibition percent for each compound was determined by comparison with a $100 \mu \mathrm{M}$ DPPH ethanol blank solution.

\subsection{Inhibition of Lipid Peroxidation on Rat Brain}

Inhibition of lipid peroxidation of FA derivatives was assayed following previous described method [17] [18].

\subsection{Cytotoxicity Assay}

All synthetized compounds were screened in vitro at doses of $50 \mu \mathrm{g} / \mathrm{mL}$ against 


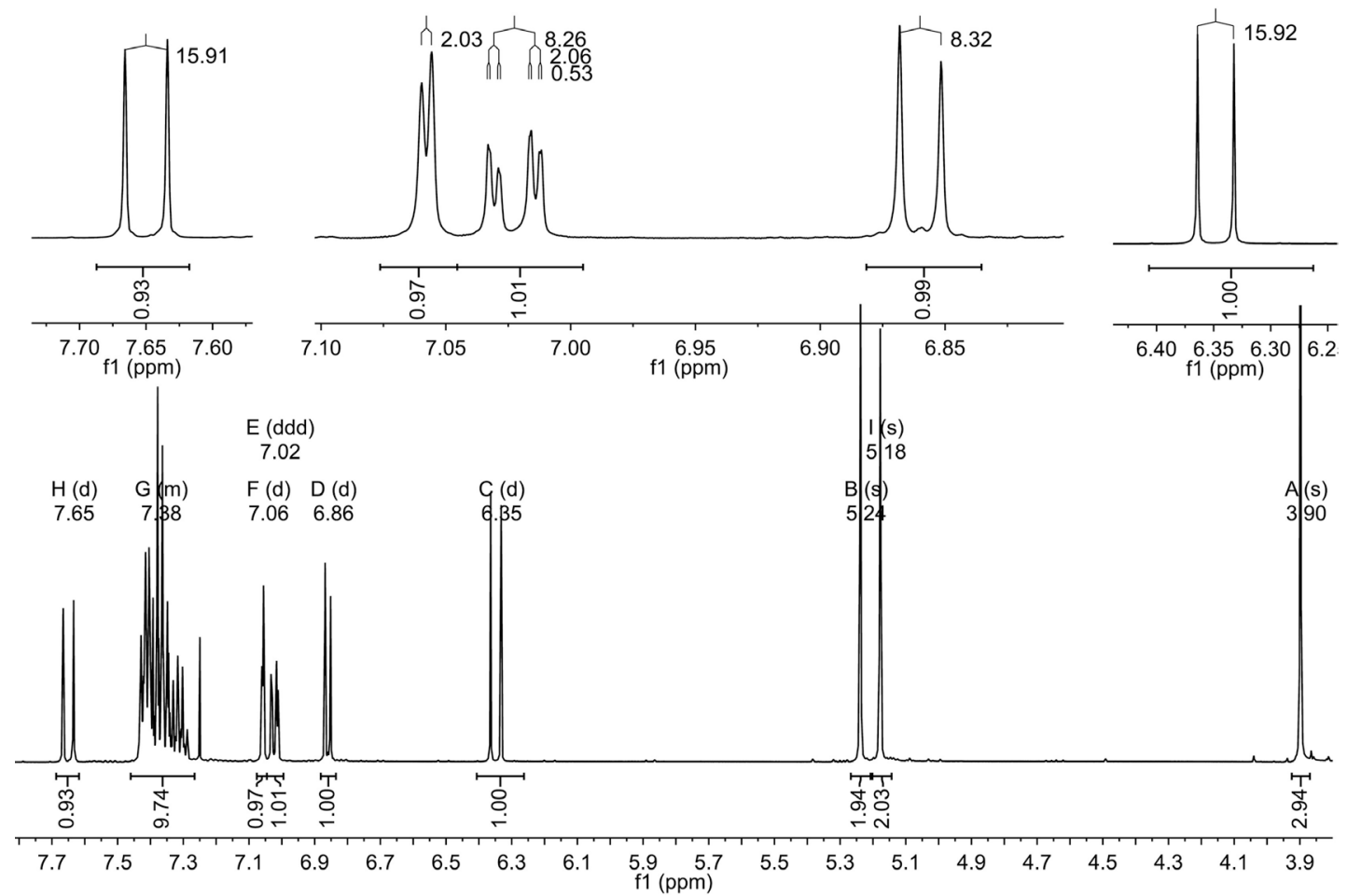

Figure 6. ${ }^{1} \mathrm{H}$ NMR spectrum of compound 6.

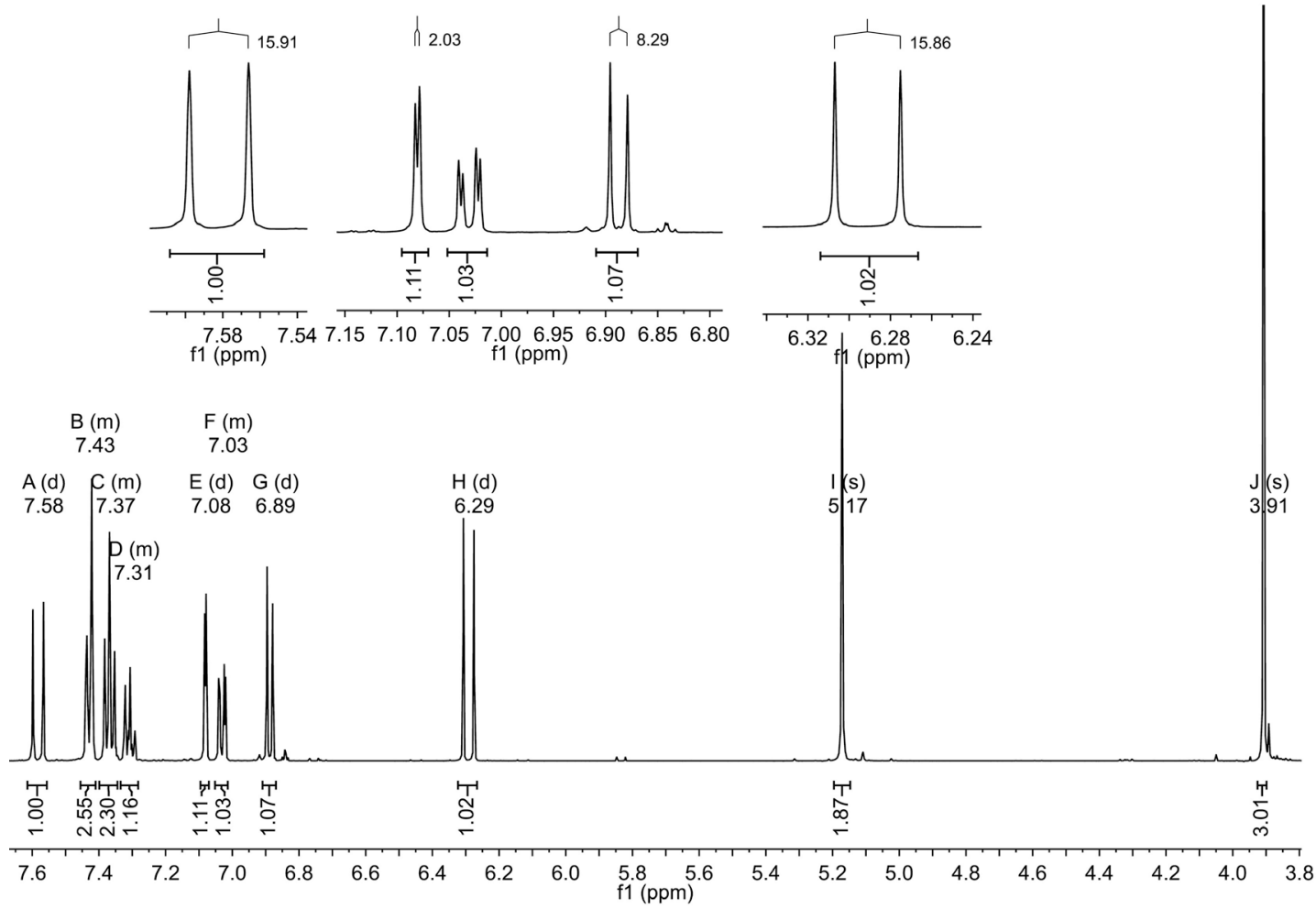

Figure 7. ${ }^{1} \mathrm{H}$ NMR spectrum of compound 7.

monkey kidney cells and cancer cell lines: U251 (central nervous system glia cancer), PC-3 (prostate adenocarcinoma), K562 (human chronic myelogenous 
leukemia), HCT-15 (colon adenocarcinoma), MCF-7 (human mammary adenocarcinoma) and SKLU-1 (human lung adenocarcinoma). Cell lines were supplied by U.S. National Cancer Institute (NCI). The human tumor cytotoxicity was determined using the protein-binding dye sulforhodamine B (SRB) in microculture assay to measure cell growth, as described in the protocols established by the NCI [19].

\section{Results and Discussion}

\subsection{Refinement Details}

All reflections were defined based on $\mathrm{F}^{2}$. The weighted $\mathrm{R}$-factor $\mathrm{wR}$ and goodness of fit $\mathrm{S}$ are based on $\mathrm{F}^{2}$, conventional $\mathrm{R}$-factors $\mathrm{R}$ are based on $\mathrm{F}$, with $\mathrm{F}$ set to zero for negative $\mathrm{F}^{2}$. The threshold expression of $\mathrm{F}^{2}>\sigma\left(\mathrm{F}^{2}\right)$ is used only for calculating R-factors (gt) etc., and is not relevant to the choice of reflections for refinement. R-factors based on $\mathrm{F}^{2}$ are statistically about twice as large as those based on F, and R-factors based on all data will be even larger.

There is an intramolecular hydrogen bond and one intermolecular hydrogen bond between the hydroxyl group at $\mathrm{C} 7$ and $\mathrm{O} 5$ with a symmetry-related molecule forming sheets along the a-axis. In structure 3 , the bond lengths and angles are similar to those found in 3-(4-Hydroxy-3-methoxyphenyl)-2-propenoic acid (ferulic acid). Molecular packing of molecules in the crystal shows an intermolecular O-H...O hydrogen-bonded carboxylic acid dimers that together with several C-H...O interactions form a sheet-like structure. In structure 4 is a new benzoyloxy and acrylate derivative of FA. The molecules in the crystal are linked by one $\mathrm{C}-\mathrm{H}$... $\mathrm{O}$ intermolecular interaction involving $\mathrm{H}$ atom of the phenyl ring C4-C9 and carbonyl oxygen of the acrylate group. This interaction links crystal and packed molecules at normal van der Waals distances. In structure 6, there are two independent molecules in the crystal. Structure 6 contains three substituents mainly at $\mathrm{C} 4$ a methoxyphenylacrylate moiety; at $\mathrm{C} 6$ a methoxy group and $\mathrm{C} 7 \mathrm{a}$ benzoyloxy moiety. The dihedral angle between phenyl rings C4-C9 and C28-C33 is only $4.76(12)^{\circ}$. There are seven C-H...O interactions that link two independent molecules in the crystal and packed structures at normal van der Waals distances. Structure 7 contains three substituents mainly at $\mathrm{C} 4$ an acrylic acid group; at $\mathrm{C} 6$ a methoxy group and $\mathrm{C} 7$ a benzoyloxy moiety. There is one intermolecular hydrogen bond $\mathrm{O}-\mathrm{H}$... $\mathrm{O}$ with a symmetry related molecule $(+2-x,+2-y,+2-z)$ forming sheets along the $b$-axis and two C-H...O interactions linked the molecules in the crystal and packed at normal van der Waals distances.

\subsection{Geometric Details}

All estimation of standard deviation (esd's) (except the esd in the dihedral angle between two least square planes) are estimated using the full covariance matrix. The cell esds are taken into account individually in the estimation of esds in distances, angles and torsion angles; correlations between esds in cell parameters 
are only used when they are defined by crystal symmetry. An approximate (isotropic) treatment of cell esds was used for estimating esds involving least square planes.

\subsection{Structural X-Ray Data}

All structures were solved by direct methods [20], and then refined by full-matrix least-squares technique; the position and anisotropic parameters of all non-hydrogen atoms were obtained. Table 1 shows the data collection and handling for compounds $2,3,4,6$, and 7 . Table 2 shows the crystal and refinement parameters for compounds $2,3,4,6$ and 7. Figure 8 contains the molecular structures of 2, 3, 4, 6 and 7. This figure was drawn with $50 \%$ displacement ellipsoids using ORTEP-3 for Windows [21]. The geometry of the molecule was calculated using PARST [22] [23] software. In all structures, the bond distances and bond angles are in good agreement with the corresponding values and are within normal ranges.
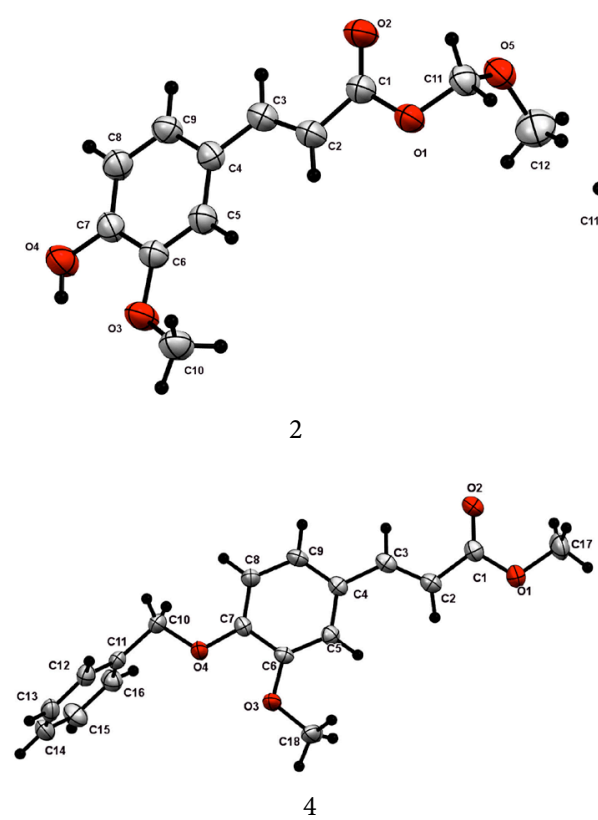

4
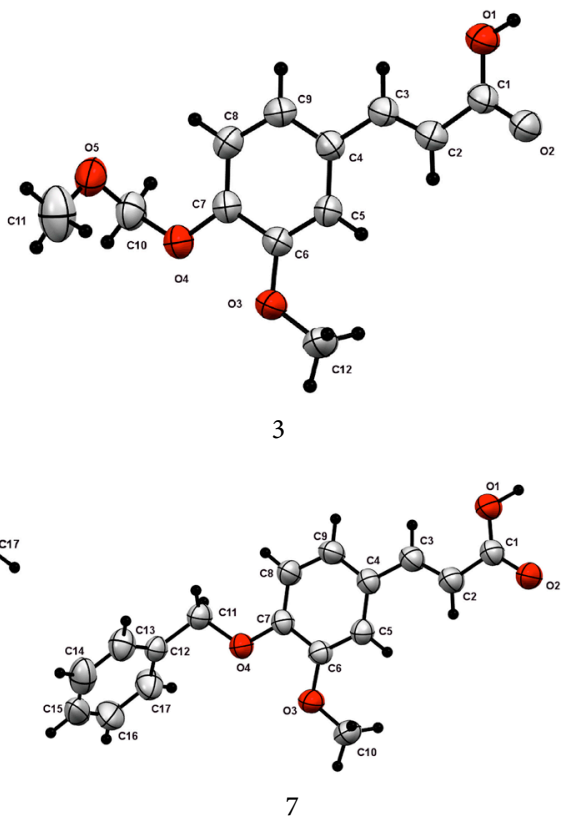

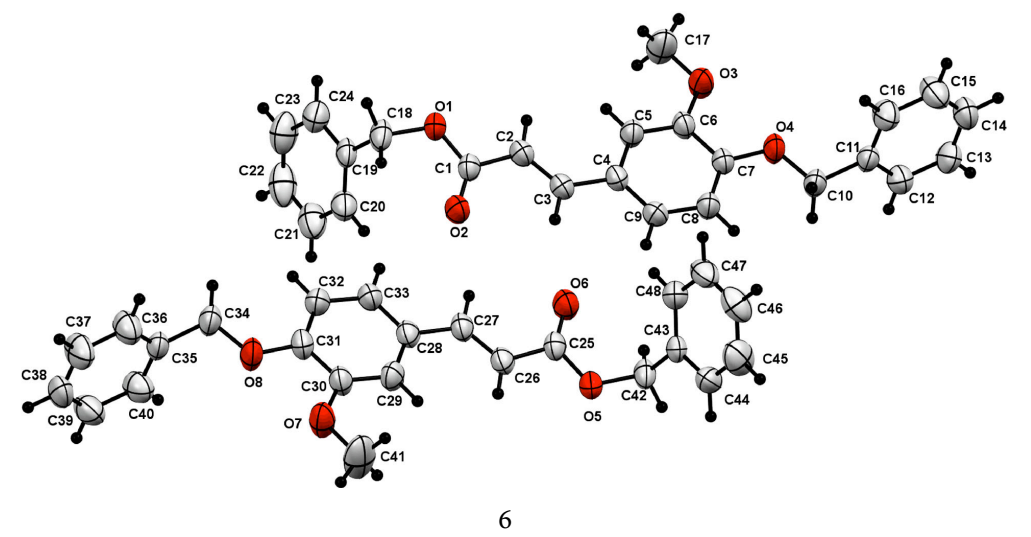

Figure 8. The molecular structures of 2, 3, 4, 6 and 7. 
Table 2. Crystal and refinement parameters for compounds 2, 3, 4, 6 and 7.

\begin{tabular}{|c|c|c|c|c|c|}
\hline Compound & 2 & 3 & 4 & 6 & 7 \\
\hline Crystal system & Monoclinic & Triclinic & Monoclinic & Monoclinic & Monoclinic \\
\hline Unitcell dimensions & $\begin{array}{l}a=12.2068(11) \AA \\
\alpha=90.00 \mathrm{deg} \\
b=9.0967(8) \AA \\
\beta=113.431(5) \mathrm{deg} \\
c=11.9634(10) \AA \\
\gamma=90.00 \mathrm{deg}\end{array}$ & $\begin{array}{l}a=6.8359(6) \AA \\
\alpha=93.459(3) \mathrm{deg} \\
b=7.8261(6) \AA \\
\beta=101.485(3) \mathrm{deg} \\
c=11.9252(10) \AA \\
\gamma=106.323 \mathrm{deg}\end{array}$ & $\begin{array}{l}a=9.5021(3) \AA \\
\alpha=90.00 \mathrm{deg} \\
b=20.2456(6) \AA \\
\beta=93.783(2) \mathrm{deg} \\
c=8.1203(2) \AA \\
\gamma=90.00 \mathrm{deg}\end{array}$ & $\begin{array}{l}a=5.6645(3) \AA \\
a=90.00 \mathrm{deg} \\
b=34.863(2) \AA \\
\beta=96.742(2) \mathrm{deg} \\
c=20.7049(14) \AA \\
\gamma=90.00) \mathrm{deg}\end{array}$ & $\begin{array}{l}a=5.3864(2) \AA \\
\alpha=90.00 \mathrm{deg} \\
b=8.5106(3) \AA \\
\beta=94.1040(10) \mathrm{deg} \\
c=31.6002(10) \AA \\
\gamma=90.00 \mathrm{deg}\end{array}$ \\
\hline Volume & $1218.89(19) \AA^{3}$ & $595.40(9) \AA^{3}$ & $1558.75(8) \AA^{3}$ & $595.40(9) \AA^{3}$ & $1444.89(9) \AA^{3}$ \\
\hline Z/Calculated density & $4 / 1.298 \mathrm{mg} / \mathrm{m}^{3}$ & $2 / 1.329 \mathrm{mg} / \mathrm{m}^{3}$ & $4 / 1.271 \mathrm{mg} / \mathrm{m}^{3}$ & $8 / 1.225 \mathrm{mg} / \mathrm{m}^{3}$ & $4 / 1.307 \mathrm{mg} / \mathrm{m}^{3}$ \\
\hline Absorption Coefficient & $0.101 \mathrm{~mm}^{-1}$ & $0.104 \mathrm{~mm}^{-1}$ & $0.089 \mathrm{~mm}^{-1}$ & $0.083 \mathrm{~mm}^{-1}$ & $0.093 \mathrm{~mm}^{-1}$ \\
\hline Space group/F (000) & $P 2_{1} / c / 504$ & $P-1 / 252$ & $P 2_{1} / c / 632$ & $C \mathrm{c} / 1584$ & $P 2_{1} / c / 600$ \\
\hline Limiting indices & $\begin{array}{l}-14 \leq \mathrm{h} \leq 14 \\
-10 \leq \mathrm{k} \leq 10 \\
-14 \leq 1 \leq 14\end{array}$ & $\begin{array}{l}-8 \leq \mathrm{h} \leq 8 \\
-9 \leq \mathrm{k} \leq 9 \\
-14 \leq 1 \leq 14\end{array}$ & $\begin{array}{l}-9 \leq \mathrm{h} \leq 11 \\
-24 \leq \mathrm{k} \leq 20 \\
-9 \leq 1 \leq 9\end{array}$ & $\begin{array}{l}-6 \leq \mathrm{h} \leq 6 \\
-42 \leq \mathrm{k} \leq 41 \\
-24 \leq 1 \leq 24\end{array}$ & $\begin{array}{l}-6 \leq \mathrm{h} \leq 6 \\
-10 \leq \mathrm{k} \leq 10 \\
-37 \leq 1 \leq 37\end{array}$ \\
\hline $\begin{array}{l}\text { Reflection scollected } \\
\text { unique/R (int) }\end{array}$ & $9089 / 2224 / 0.0367$ & $9223 / 2181 / 0.0622$ & $8788 / 2835 / 0.0528$ & $32,474 / 6927 / 0.1218$ & $16172 / 2654 / 0.0702$ \\
\hline Completeness to $\theta=25.10$ & $99.9 \%$ & $99.9 \%$ & $99.9 \%$ & $99.8 \%$ & $99.9 \%$ \\
\hline Max/min Transmission & $0.961 / 0.990$ & $0.958 / 0.984$ & $0.965 / 0.994$ & $0.976 / 0.995$ & $0.970 / 0.983$ \\
\hline Data/restraints/parameters & $2224 / 0 / 160$ & $2181 / 1 / 159$ & $2835 / 0 / 201$ & $6927 / 2 / 507$ & $2654 / 1 / 194$ \\
\hline Final $\mathrm{R}$ indices & $\mathrm{R} 1=0.0403$ & $\mathrm{R} 1=0.0441$ & $\mathrm{R} 1=0.0414$ & $\mathrm{R} 1=0.0484$ & $\mathrm{R} 1=0.0458$ \\
\hline $\mathrm{I}>2 \sigma(\mathrm{I})$ & $\mathrm{wR} 2=0.1182$ & $\mathrm{wR} 2=0.1228$ & $\mathrm{wR} 2=0.0880$ & $\mathrm{wR} 2=0.1137$ & $\mathrm{wR} 2=0.1111$ \\
\hline $\mathrm{R}$ indices (all data) & $\begin{array}{l}\mathrm{R} 1=0.0553 \\
\mathrm{wR} 2=0.1260\end{array}$ & $\begin{array}{l}\mathrm{R} 1=0.0517 \\
\mathrm{wR} 2=0.1297\end{array}$ & $\begin{array}{l}\mathrm{R} 1=0.0717 \\
\mathrm{wR} 2=0.1045\end{array}$ & $\begin{array}{l}\mathrm{R} 1=0.0773 \\
\mathrm{wR} 2=0.1286\end{array}$ & $\begin{array}{l}\mathrm{R} 1=0.0790 \\
\mathrm{wR} 2=0.128\end{array}$ \\
\hline Goodness-of-fit on $\mathrm{F}^{2}$ & 1.059 & 1.070 & 0.998 & 1.030 & 1.019 \\
\hline Largest diff. peak/hole & $0.211 /-0.185$ e. $\AA^{-3}$ & $0.178 /-0.162$ e. $\AA^{-3}$ & $0.208 /-0.241$ e..$\AA^{-3}$ & $0.150 /-0.138$ e. $\AA^{-3}$ & $0.189 /-0.178$ e. $\AA^{-3}$ \\
\hline CCDC deposition number & $1,825,526$ & $1,825,528$ & $1,825,527$ & $1,825,529$ & $1,825,523$ \\
\hline
\end{tabular}

Compound 2 crystallizes in the monoclinic space group $P 2_{1} / c$ with unit cell parameters $a=12.2068(11), b=9.0967(8), c=11.963421(10) \AA, \beta=113.431$ (5), $\mathrm{Z}=4$. Compound 3 crystallizes in the triclinic space group $P$-1 with unit cell parameters $a=6.8359$ (6), $b=7.8261$ (6), $c=11.9252$ (10) $\AA, \alpha=93.459$ (3), $\beta=101.485$ (3), $\gamma=106.323(2)^{\circ}, Z=2$. Compound 4 crystallizes in the monoclinic space group $P 2_{1} / c$ with unit cell parameters $a=9.5021$ (3), $b=20.2456$ (6), $c=8.1203$ (2) $\AA, \beta=93.783$ (2), $Z=4$. Compound 6 crystallizes in the monoclinic space group $C c$ with unit cell parameters $a=5.6645$ (3), $b=34.863$ (2), $c=20.7049$ (14) $\AA, \beta=96.742$ (2), $\mathrm{Z}=8$. Compound 7 crystallizes in the monoclinic space group $P 2_{1} / c$ with unit cell parameters $a=5.3864$ (2), $b=$ 8.5106 (3), $c=31.6002(10) \AA ̊ \Omega, \beta=94.1040(10), Z=4$.

The molecular structure of $\mathbf{2}$ is not planar, with a fully extended methoxymethyl group of the acrylate residue as shown in Figure 8. The dihedral angle between the side chain at $\mathrm{C} 4$ and the phenyl ring is $32.7(2)^{\circ}$. The hydroxyl group at $\mathrm{C} 7$ has an intramolecular hydrogen with $\mathrm{O} 3$ and one intermolecular hydrogen bond between the hydroxyl group at $\mathrm{C} 7$ and $\mathrm{O} 5$ with a symmetry related molecule $(-x-1,+y,+z)$ forming sheets along the a-axis. There are no stacking interactions between phenyl rings. The crystal packing diagram is shown in Figure 9. 

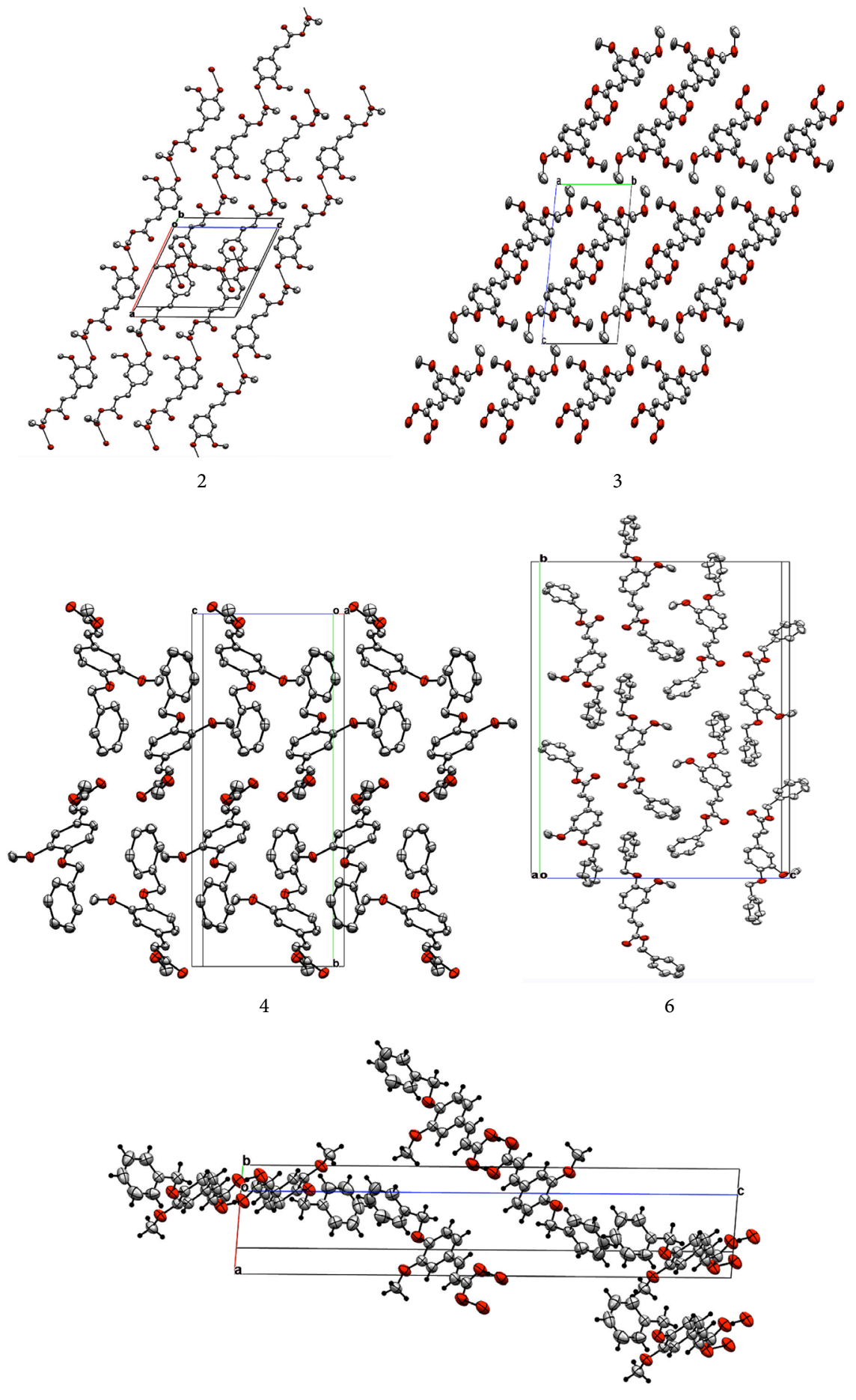

7

Figure 9. The molecular packing of structures 2, 3, 4, 6 and 7.

Figure 8 shows the molecular structure of 3 . Bond lengths and angles are similar to those found in 3-(4-Hydroxy-3-methoxyphenyl)-2-propenoic acid (FA) [24]. The dihedral angles between the side chain at C4, the acrylate and the phenyl ring are 48.31 (5) and $9.32(5)^{\circ}$, respectively. The molecular packing of 3 in the crystal shows an intermolecular O-H...O hydrogen-bonded carboxylic 
acid dimers that together with several C-H...O interactions form a sheet-like structure (Figure 9).

The molecular structure of 4 corresponds to a new benzoyloxy and acrylate derivative of ferulic acid. There are no significant molecular distortions in terms of bond lengths and angles. The dihedral angles between benzene ring $\mathrm{C} 4$ to $\mathrm{C} 9$ and the side chains at $\mathrm{C} 4$ and $\mathrm{C} 7$ are 21.25 (5) and $8.84(5)^{\circ}$, respectively. However, the benzene ring $\mathrm{C} 4$ to $\mathrm{C} 9$ makes and angle of 86.00 (5) ${ }^{\circ}$ with the benzene ring $\mathrm{C} 11$ to $\mathrm{C} 16$. The molecule 4 in the crystal are linked by one $\mathrm{C}-\mathrm{H} . . . \mathrm{O}$ intermolecular interaction involving an $\mathrm{H}$ atom of the phenyl ring $\mathrm{C} 4-\mathrm{C} 9$ and carbonyl oxygen of the acrylate group. This interaction linked the molecules in the crystal and packed at normal van der Waals distances (Figure 9).

Figure 8 shows the molecular structure of compound 6 . There are two independent molecules 4 in the crystal. Molecule 6 contains three substituents mainly at $\mathrm{C} 4$ a methoxyphenyl acrylate moiety; at $\mathrm{C} 6$ a methoxy group and C7 a benzoyloxy moiety. The dihedral angles between phenyl rings C11-C16 and C19-C24 with the central phenyl ring C4-C9 are 70.50 (12) and 69.61 (14), respectively. The dihedral angles between phenyl rings C35-C40 and C43-C48 with the central phenyl ring C28-C33 are 77.00 (14) and 73.92 (16), respectively. The dihedral angle between the phenyl rings $\mathrm{C} 4-\mathrm{C} 9$ and $\mathrm{C} 28-\mathrm{C} 33$ is only $4.76(12)^{\circ}$. There are seven $\mathrm{C}-\mathrm{H}$...O interactions linked the two independent molecules in the crystal packed at normal van der Waals distances (Figure 9).

The molecular structure of $\mathbf{7}$ is shown in Figure 8. The molecule contains three substituents mainly at $\mathrm{C} 4$ an acrylic acid group; at C6, a methoxy group and at $\mathrm{C} 7$ a benzoyloxy moiety. The dihedral angles between phenyl ring C12-C17; the linker C7-O4-C11-C12 and acrylic acid group at C4 with the central phenyl ring C4-C9 are 74.62 (6), 12.17 (9) and $7.37(5)^{\circ}$, respectively. There is one intermolecular hydrogen bond $\mathrm{O}-\mathrm{H}$... O with a symmetry related molecule $(+2-x,+2-y,+2-z)$ forming sheets along the $b$-axis and two C-H... interactions linked the molecules in the crystal and packed at normal van der Waals distances (Figure 9).

For geometrical details and notations of all of these hydrogen bonds and intermolecular interactions are given in Table 3.

\subsection{Biological Assay}

Interestingly, compounds 1, 2 and 5, with free hydroxyl group, showed to have DPPH free radicals scavenging activity in vitro in moderate to high level (see Table 4). These results are consistent with a previous report, where it is postulated that antioxidant property of FA and its derivatives is associated with the number of free hydroxyl groups on the benzene ring and ortho substitution with the electron donor methoxy group, due to stabilization of the phenoxy radical [25]. FA derivatives, especially those with etherified phenolic groups, did not show effect upon the free radical essay. 
Table 3. Geometry of the hydrogen bonds and hydrogen bonding interactions $\left(\AA{ }^{\circ}{ }^{\circ}\right)$ for compounds $2,3,4,6$ and 7 .

\begin{tabular}{|c|c|c|c|c|c|c|}
\hline Compound & $\mathrm{D}-\mathrm{H} \ldots A$ & $\mathrm{D}-\mathrm{H}$ & Н...A & $\mathrm{D} \ldots A$ & $\mathrm{D}-\mathrm{H} \ldots A$ & Symmetrycode \\
\hline \multirow{3}{*}{2} & $\mathrm{O} 4-\mathrm{H} 4 \ldots \mathrm{O} 3$ & $0.82(2)$ & $2.25(3)$ & $2.661(2)$ & $111(2)$ & $x, y, z$ \\
\hline & $\mathrm{O} 4-\mathrm{H} 4 \ldots \mathrm{O} 5$ & $0.82(2)$ & $1.97(2)$ & $2.731(2)$ & $156(2)$ & $x, y, z$ \\
\hline & C8-H8...O2 & $0.930(2)$ & $2.920(1)$ & $3.431(2)$ & $116.1(1)$ & $2-x,-y, 2-z$ \\
\hline \multirow{5}{*}{3} & C8-H8_..O5 & $0.930(1)$ & $2.553(1)$ & $3.081(2)$ & $116.4(1)$ & $x, y, z$ \\
\hline & $\mathrm{O} 1-\mathrm{H} 1 \ldots \mathrm{O} 2$ & $0.86(2)$ & $1.77(2)$ & $2.635(2)$ & $179(2)$ & $+3-x,+1-y,+1-z$ \\
\hline & $\mathrm{C} 8-\mathrm{H} 8 \ldots \mathrm{O} 2$ & $0.930(1)$ & $2.612(1)$ & $3.294(2)$ & $130.7(1)$ & $-1+x,-1+y, z$ \\
\hline & $\mathrm{C} 9-\mathrm{H} 9 \ldots \mathrm{O} 2$ & $0.930(2)$ & $2.889(1)$ & $3.434(2)$ & $118.7(1)$ & $-1+x,-1+y, z$ \\
\hline & $\mathrm{C} 12-\mathrm{H} 12 \ldots \mathrm{O} 3$ & $0.960(3)$ & $2.720(1)$ & $3.348(3)$ & $123.61(1)$ & $+1-x,+1-y,+2-z$ \\
\hline \multirow[t]{4}{*}{4} & $\mathrm{C} 9-\mathrm{H} 9 \ldots \mathrm{O} 2$ & $0.950(2)$ & $2.394(1)$ & $3.324(2)$ & $165.8(1)$ & $-x,+1-y,+1-z$ \\
\hline & $\mathrm{C} 3-\mathrm{H} 3 \ldots \mathrm{O} 6$ & $0.930(4)$ & $2.516(3)$ & $3.411(5)$ & $161.7(3)$ & $x, y, z$ \\
\hline & $\mathrm{C} 20-\mathrm{H} 20 \ldots \mathrm{O} 2$ & $0.930(5)$ & $2.686(3)$ & $3.294(5)$ & $123.7(3)$ & $x, y, z$ \\
\hline & C27-H27...O2 & $0.931(4)$ & $2.526(3)$ & $3.425(5)$ & $162.5(3)$ & $x, y, z$ \\
\hline \multirow[t]{5}{*}{6} & C48-H48...O6 & $0.930(4)$ & $2.612(3)$ & $3.216(5)$ & $123.1(3)$ & $x, y, z$ \\
\hline & $\mathrm{C} 3-\mathrm{H} 3 \ldots \mathrm{O} 1$ & $0.930(4)$ & $2.958(3)$ & $3.410(5)$ & $111.5(3)$ & $+1+x, y, z$ \\
\hline & C17-H17...O3 & $0.959(6)$ & $2.685(3)$ & $3.370(7)$ & $128.8(4)$ & $+1-x,+1-y,+2-z$ \\
\hline & C18-H18A...O2 & $0.970(5)$ & $2.560(3)$ & $3.489(5)$ & $160.6(3)$ & $-1+x, y, z$ \\
\hline & $\mathrm{O} 1-\mathrm{H} 1 \ldots \mathrm{O} 2$ & $1.01(3)$ & $1.62(3)$ & $2.6213(2)$ & $175(2)$ & $+2-x,+2-y,+2-z$ \\
\hline \multirow[t]{2}{*}{7} & $\mathrm{C} 8-\mathrm{H} 8 \ldots \mathrm{O} 2$ & $0.930(2)$ & $2.509(2)$ & $3.433(3)$ & $172.3(1)$ & $-1+x,-1+y, z$ \\
\hline & С9-H9...O1 & $0.930(2)$ & $2.701(2)$ & $3.437(3)$ & $136.7(1)$ & $+1+x,+1-y,+2-z$ \\
\hline
\end{tabular}

Table 4. Preliminary antioxidant and cytotoxic activity of FA derivatives.

\begin{tabular}{|c|c|c|c|c|c|c|c|c|c|c|c|}
\hline \multirow[b]{2}{*}{ Compound } & \multicolumn{2}{|c|}{$\begin{array}{l}\text { Scavenging activity } \\
\text { DPPH }\end{array}$} & \multicolumn{2}{|c|}{$\begin{array}{l}\text { Inhibition of lipid } \\
\text { peroxidation TBARS }\end{array}$} & \multicolumn{7}{|c|}{$\begin{array}{c}\text { Cytotoxic activity } \\
\text { Percentage of inhibition of cell lines at } 50 \mu \mathrm{M}\end{array}$} \\
\hline & $10 \mu \mathrm{M}$ & $100 \mu \mathrm{M}$ & $10 \mu \mathrm{M}$ & $100 \mu \mathrm{M}$ & U251 & PC-3 & K562 & HCT-15 & MCF-7 & SKLU-1 & COS-7 \\
\hline $\mathrm{FA}$ & $19.90 \pm 0.26$ & $76.81 \pm 0.26^{\star}$ & $-4.07 \pm 3.82$ & $4.06 \pm 1.36$ & NC & $\mathrm{NC}$ & $\mathrm{NC}$ & $\mathrm{NC}$ & NC & $\mathrm{NC}$ & ND \\
\hline 1 & $11.76 \pm 0.31$ & $60.39 \pm 0.13^{*}$ & $10.51 \pm 4.03$ & $34.52 \pm 3.05^{*}$ & $\mathrm{NC}$ & 4.8 & 26.6 & $\mathrm{NC}$ & NC & 18.6 & 1.2 \\
\hline 2 & $9.95 \pm 0.38$ & $56.76 \pm 0.29^{\star}$ & $12.24 \pm 2.37$ & $30.19 \pm 2.13^{\star}$ & $\mathrm{NC}$ & $\mathrm{NC}$ & 7.7 & $\mathrm{NC}$ & $\mathrm{NC}$ & $\mathrm{NC}$ & $\mathrm{NC}$ \\
\hline 3 & $5.39 \pm 0.32$ & $30.10 \pm 0.39^{*}$ & $2.02 \pm 2.20$ & $1.45 \pm 3.14$ & $\mathrm{NC}$ & 8 & 20.3 & NC & 6.5 & 12 & 7.0 \\
\hline 4 & $0.49 \pm 0.38$ & $0.39 \pm 0.05$ & $4.31 \pm 1.45$ & $7.48 \pm 2.80$ & NC & 24.8 & 72.5 & 16.3 & $\mathrm{NC}$ & 20.9 & 17.7 \\
\hline 5 & $12.84 \pm 0.24$ & $59.95 \pm 0.25^{\star}$ & $40.61 \pm 1.60^{*}$ & $96.68 \pm 0.65^{\star}$ & 25.5 & 59.4 & 48.0 & 26.9 & 25.4 & 20.2 & 52.6 \\
\hline 6 & $1.03 \pm 0.31$ & $0.83 \pm 0.13$ & $6.08 \pm 0.98$ & $9.16 \pm 2.71$ & NC & 15.3 & 32.4 & 15.5 & 14.6 & 27.4 & 31.3 \\
\hline 7 & $1.27 \pm 0.19$ & $3.19 \pm 0.47$ & $7.46 \pm 12.71$ & $13.8 \pm 25.14$ & 5.8 & 16.6 & 17 & 5.7 & 7.8 & 18.1 & 22.2 \\
\hline
\end{tabular}

Data represent media and standard error. ${ }^{\star} P \leq 0.05$ compared to $\mathrm{FeSO}_{4}$ control. ${ }^{\star} P \leq 0.05$ compared to DPPH control. FA: ferulic acid. Cell lines: $\mathrm{U} 251$ : central nervous system glia cancer, PC-3: prostate adenocarcinoma, K562: human chronic myelogenous leukemia, HCT-15: colon adenocarcinoma, MCF-7: human mammary adenocarcinoma, SKLU: human lung adenocarcinoma, COS7: non-cancerous monkey kidney cell line. NC: non-cytotoxic, ND: non determinated.

Moreover, compounds 1, 2 and 5 also inhibited lipoperoxidation induced by ferric sulphate in the rat brain, mainly due to preservation of phenolic group and a similar mechanism of action of antioxidant effect described above. Remarkably, compound 7 showed moderate inhibition of lipid peroxidation, despite the fact of it has the phenol group blocked probably due to higher lipophilicity, which aids to penetrate the cell membrane where lipid peroxidation takes place 
[26].

The FA derivatives showed low cytotoxic activity in the preliminary screening in different cancer cell lines (all compounds were tested at $50 \mu \mathrm{M}$ ). As seen in Table 4, only compound 5 inhibited cancer cell lines PC-3 and K562 by $59 \%$ and $48 \%$ respectively, while to healthy cell line COS- 7 it did so by $53 \%$. Compounds 4 and 6 also inhibited the growth of K562 cell line by 72\% and 32\% respectively. Since there were not relevant cytotoxic agents, it is remarkable that addition of benzyl groups to the FA improved cytotoxic activity in vitro, possibly by the increment of lipophilicity of compounds and a more efficient molecular action within the cell, as it has been reported previously [27] [28]. Our findings do not coincide with Jayaprakasam et al. (2006), who reported anti-inflammatory, anticancer and antioxidant activity of FA esters at low concentrations [29]. New refined analyses are required in order to elucidate molecular effects of FA and its derivatives.

\section{Conclusion}

The synthesis with moderate to good yields and unambiguous assignment of chemical structures of methoxymethyl (E)-3-(4-hydroxy-3-methoxyphenyl)acrylate $\left(\mathrm{C}_{12} \mathrm{H}_{14} \mathrm{O}_{5}\right)$ 2; (E)-3-(3-methoxy-4-(methoxy methoxy)phenyl)acrylic acid $\left(\mathrm{C}_{12} \mathrm{H}_{14} \mathrm{O}_{5}\right)$ 3; methyl (E)-3-(4-(benzyloxy)-3-methoxyphenyl)acrylate $\left(\mathrm{C}_{18} \mathrm{H}_{18} \mathrm{O}_{4}\right)$ 4; benzyl (E)-3-(4-(benzyloxy)-3-methoxyphenyl)acrylate $\left(\mathrm{C}_{24} \mathrm{H}_{22} \mathrm{O}_{5}\right) 6$ and (E)-3-(4-(benzyloxy)-3-methoxyphenyl) acrylic acid $\left(\mathrm{C}_{17} \mathrm{H}_{16} \mathrm{O}_{4}\right) 7$ was achieved using ${ }^{1} \mathrm{H} /{ }^{13} \mathrm{C}$ NMR and X-ray techniques of compounds 2, 3 4, 6 and 7 were successfully grown single crystals. Compounds containing free phenolic hydroxyls e.g. 1, 2 and $\mathbf{5}$ exhibited scavenging free radical and antioxidant activity. Compound $\mathbf{5}$ induced significant inhibition of cell growth in PC-3, K562 and COS-7 cell lines by $59.4 \%, 52.6 \%$ and $48 \%$ respectively while 4 exhibited the largest cytotoxic effect upon K562 cell line i.e. $72.5 \%$.

\section{Supplementary Materials}

CCDC-1825526, CCDC-1825528, CCDC-1825527, CCDC-1825529 and CCDC- 1852523 contain the supplementary crystallographic data for compound 2, 3, 4, 6 and 7, respectively. These data can be obtained free of charge via https://www.ccdc.cam.ac.uk/structures/ by e-mailing data_request@ccdc.cam.ac.uk, or by contacting The Cambridge Crystallographic Data Centre, 12 Union Road, Cambridge CB2 1EZ, UK, fax; +44(0)1223-336033.

\section{Acknowledgements}

Financial support from projects DGAPA (PAPIIT) UNAM (IN208516) and CONACyT (CB-252524) is gratefully acknowledged. Technical assistance is acknowledged from Simón Hernández-Ortega X-ray, Rocio Patiño and María de la Paz Orta for IR spectra; Isabel Chavéz, Hector Ríos and Rubén Gaviño for NMR spectra, Luis Velasco for MS spectra, Maria Teresa Ramírez-Apan and Antonio 
Nieto for biological assays. Support from CONACYT scholarships to Marco A. Obregón-Mendoza (603692), William Meza-Morales (576707) and Yair Alvarez-Ricardo (576706) is acknowledged.

\section{Conflicts of Interest}

The authors declare no conflicts of interest regarding the publication of this paper.

\section{References}

[1] Kumar, N., Kumar, S., Abbat, S. Nikhil, K., Sondhi, S., Bharatam, P., Roy, P. and Pruthi, V. (2016) Ferulic Acid Amide Derivatives as Anticancer and Antioxidant Agents: Synthesis, Thermal, Biological and Computational Studies. Medicinal Chemistry Research, 25, 1175-1192. https://doi.org/10.1007/s00044-016-1562-6

[2] Zhao, Z.H. and Moghadasian, M.H. (2008) Chemistry, Natural Sources, Dietary Intake and Pharmacokinetic Properties of Ferulic Acid: A Review. Food Chemistry, 109, 691-702. https://doi.org/10.1016/j.foodchem.2008.02.039

[3] Kumar, N. and Pruthi, V. (2014) Potential Applications of Ferulic Acid from Natural Sources. Biotechnology Reports, 4, 86-93. https://doi.org/10.1016/j.btre.2014.09.002

[4] Graf, E. (1992) Antioxidant Potential of Ferulic Acid. Free Radical Biology \& Medicine, 13, 435-448. https://doi.org/10.1016/0891-5849(92)90184-I

[5] Mori, H., Kawabata, K., Yoshimi, N., Tanaka, T., Murakami, T., Okada, T. and Murai, H. (1999) Chemopreventive Effects of Ferulic Acid on Oral and Rice Germ on Large Bowel Carcinogenesis. Anticancer Research, 19, 3775-3783.

[6] Srinivasan, M., Sudheer, A.R. and Menon, V.P. (2007) Ferulic Acid: Therapeutic Potential through Its Antioxidant Property. Journal of Clinical Biochemistry and Nutrition, 40, 92-100. https://doi.org/10.3164/jcbn.40.92

[7] Mathew, S. and Abraham, T.E. (2004) Ferulic Acid: An Antioxidant Found Naturally in Plant Cell Walls and Feruloyl Esterases Involved in Its Release and Their Applications. Critical Reviews in Biotechnology, 24, 59-83. https://doi.org/10.1080/07388550490491467

[8] Kikuzaki, H., Hisamoto, M., Hirose, K., Akiyama, K. and Taniguchi, H. (2002) Antioxidant Properties of Ferulic Acid and Its Related Compounds. Journal of Agricultural \& Food Chemistry, 50, 2161-2168. https://doi.org/10.1021/jf011348w

[9] Li, W.X., Li, N.G., Tang, Y.P., Li, B.Q., Liu, L., Zhang, X., Fu, H.A. and Duan, J.-A. (2012) Biological Activity Evaluation and Structure-Activity Relationships Analysis of Ferulic Acid and Caffeic Acid Derivatives for Anticancer. Bioorganic \& Medicinal Chemistry Letters, 22, 6085-6088. https://doi.org/10.1016/j.bmcl.2012.08.038

[10] Han, Y., Wu, C.L., Lv, H.F., Liu, N. and Deng, H.Y. (2015) Novel Tranylcypromine/Hydroxylcinnamic Acid Hybrids as Lysine-Specific Demethylase 1 Inhibitors with Potent Antitumor Activity. Chemical and Pharmaceutical Bulletin, 63, 882-889. https://doi.org/10.1248/cpb.c15-00476

[11] Barma, D.K., Kundu, A., Bandyopadhyay,A., Kundu, A., Sangras, B., Briot, A., Mioskowski, C. and Falck, J.R. (2004) Highly Stereospecific Synthesis of (E)- $\alpha, \beta$ Unsaturated Esters. Tetrahedron Letters, 45, 5917-5920. https://doi.org/10.1016/j.tetlet.2004.05.113

[12] Lee, I.-K., Han, M.-S., Kim, D.-W. and Yun, B.-S. (2014) Phenylpropanoid Acid Es- 
ters from Korean Propolis and Their Antioxidant Activities. Bioorganic \& Medicinal Chemistry Letters, 24, 3503-3505. https://doi.org/10.1016/j.bmcl.2014.05.065

[13] Das, K., Anantha Reddy, S. and Mukkanti, K. (2007) Total Synthesis of Phenylpropanoid Glycosides, Grayanoside A and Syringalide B, through a Common Intermediate. Carbohydrate Research, 342, 2309-2315. https://doi.org/10.1016/j.carres.2007.06.022

[14] Armarego, W.L.F. and Perrin, D.D. (1997) Purification of Laboratory Chemicals. 4th Edition, Butterworth Heinemann, Oxford.

[15] Bruker (2009) APEX2, SAINT and SADABS. Bruker AXS Inc., Madison.

[16] Mellors, A. and Tappel, A.L. (1966) The Inhibition of Mitochondrial Peroxidation by Ubiquinone and Ubiquinol. Journal of Biological Chemistry, 241, 4353-4356. http://www.jbc.org/content/241/19/4353.full.html\#ref-list-1

[17] Obregón-Mendoza, M.A., Estévez-Carmona, M.M., Hernández-Ortega, S., Soriano-García, M., Ramírez-Apán, M.T., Orea, L., Pilotzi, H., Gnecco, D., Cassani, J. and Enríquez, R. (2017) Retro-Curcuminoids as Mimics of Dehydrozingerone and Curcumin: Synthesis, NMR, X-Ray, and Cytotoxic Activity. Molecules, 22, 33-47. https://doi.org/10.3390/molecules22010033

[18] Lozada, M.C., Soria-Arteche, O., Ramírez-Apán, M.T., Nieto-Camacho, A., Enríquez, R.G., Izquierdo, T. and Jiménez-Corona, A. (2012) Synthesis, Cytotoxic and Antioxidant Evaluations of Amino Derivatives from Perezone. Bioorganic \& Medicinal Chemistry, 20, 5077-5084. https://doi.org/10.1016/j.bmc.2012.07.027

[19] Monks, A., Scudiero, D., Skehan, P., Shoemaker, R., Paul, K., et al. (1991) Feasibility of a High-Flux Anticancer Drug Screen Using a Diverse Panel of Cultured Human Tumor Cell Lines. Journal of the National Cancer Institute, 83, 757-766. https://doi.org/10.1093/jnci/83.11.757

[20] Sheldrick, G.M. (2007) A Short History of SHELX. Acta Crystallographica A, 64, 112-122. https://doi.org/10.1107/S0108767307043930

[21] Farrugia, L.J. (2012) WinGX and ORTEP for Windows: An Update. Journal of Applied Crystallography, 45, 849-854. https://doi.org/10.1107/S0021889812029111

[22] Nardelli, M. (1983) PARST: A System of Fortran Routines for Calculating Molecular Structure Parameters from Results of Crystal Structure Analyses. Computers \& Chemistry, 7, 95-98. https://doi.org/10.1016/0097-8485(83)85001-3

[23] Nardelli, M. (195) PARST95-An Update to PARST: A System of Fortran Routines for Calculating Molecular Structure Parameters from the Results of Crystal Structure Analyses. Journal of Applied Crystallography, 28, 659. https://doi.org/10.1107/S0021889895007138

[24] Nethaji, M., Pattabhi, V. and Desiraju, G.R. (1988) Structure of 3-(4-Hydroxy3-methoxyphenyl)-2-propenoic Acid (Ferulic Acid). Acta Crystallographica C, 44, 275-277. https://doi.org/10.1107/S0108270187009211

[25] Chen, J.H. and Ho, C.T. (1997) Antioxidant Activities of Caffeic Acid and Its Related Hydroxycinnamic Acid Compounds. Journal of Agricultural and Food Chemistry, 45, 2374-2378. https://doi.org/10.1021/jf970055t

[26] Zhang, L., Al-Swayeh, S.A., Hsieh, P. and Fang, J. (2010) A Comparison of Skin Delivery of Ferulic Acid and Its Derivatives: Evaluation of Their Efficacy and Safety. International Journal of Pharmaceutics, 399, 44-51. https://doi.org/10.1016/j.ijpharm.2010.07.054

[27] Janicke, B., Hegardt, C., Krogh, M., Onning, G., Akesson, B., Cirenajwis, H.M. and Oredsson, S.M. (2011) The Antiproliferative Effect of Dietary Fiber Phenolic Com- 
pounds Ferulic Acid and p-Coumaric Acid on the Cell Cycle of Caco-2 Cells. Nutrition and Cancer, 63, 611-622. https://doi.org/10.1080/01635581.2011.538486

[28] Mancuso, C. and Santangelo, R. (2014) Ferulic Acid: Pharmacological and Toxicological Aspects. Food and Chemical Toxicology, 65, 185-195.

https://doi.org/10.1016/j.fct.2013.12.024

[29] Jayaprakasam, B., Vanisree, M., Zhang, Y., Dewitt, D.L. and Nair, M.G. (2006) Impact of Alkyl Esters of Caffeic and Ferulic Acids on Tumor Cell Proliferation, Cyclooxygenase Enzyme, and Lipid Peroxidation. Journal of Agricultural and Food Chemistry, 54, 5375-5381. https://doi.org/10.1021/jf060899p 